\title{
IMMANUEL KANT'S THEORY OF LAUGHTER AND PHILOSOPHICAL IRONY
}

Stoliar M. B.

\section{INTRODUCTION}

When we study various philosophical points of view on nature, causes and functions of laughter, the first thing that catches our eye is the antinomic character of the corresponding discourse. Almost every aspect of theoretical study of laughter practices is represented by opposing statements. Whether it is about social or biological understanding of laughter; about its rational or sensual character; about different "laughters" or "laughter in general"; about its moral usefulness or immorality; about the opposition of laughter practices to the authoritarian ideology or the conventional nature of relevant discourses, etc., each time we come across not a "wrong" or "right" understanding, but a whole range of invariant solutions. Each of them has its own argumentation, the scope of practical verification and, accordingly, its own right to exist. Still, at the same time, not a single philosophical paradigm is able to put an end to a long discussion about the nature and essence of laughter as a kind of "thing in itself". The sum of these positions and paradigms in their interaction and development comprises the philosophy of laughter.

There are also diametrically opposed points of view as to the content of the philosophy of laughter. For some, laughter is the "pseudo-being"1 a "rare topic" of philosophizing", which has a "bad reputation"3. For other philosophers, on the contrary, laughter plays a "central role in mental life and social discourse", and is seen as a crucial factor shaping a high quality of life ${ }^{5}$.

A positive attitude to laughter, as well as a statement of the importance of the corresponding philosophical reflections, comes from the understanding that laughter is "at the intersection ... of the basic coordinates of the human

${ }^{1}$ Бондаренко А.В. Языковая онтология смеховой культуры. URL: http://cheloveknauka.com/ yazykovaya-ontologiya-smehovoy-kultury (дата звернення: 15.12.2019).

${ }^{2}$ Berger Arthur Asa. An Anatomy of Humor. New Brunswick, N.J., U.S.A.: Transaction Publishers, 1993. URL: https://books.google.com.ua/books?id=aZkRJJnc6BUC\&printsec= frontcover\&hl=ru\#v=onepage \&q\&f=false (дата звернення: 10.12.2019).

Philosophy of Humor. Stanford Encyclopedia of Philosophy. URL: https://plato.stanford.edu/entries/humor/ (дата звернення: 15.11.2019).

${ }^{4}$ Olin L. Questions for a Theory of Humor. Philosophy Compass. 2016. 11(6). P. 346.

5 Amir L. Humor and the good life in modern philosophy: Shaftesbury, Hamann, Kierkegaard. Albany: State University of New York Press. 2014. 
world-attitude" ${ }^{\text {. }}$. A negative attitude to the degree of philosophical content of the topic of laughter is also not groundless. Firstly, the amazing variety of laughter practices is opposed to the philosophy of laughter. Even Jean-Paul (1763-1825) noted that the funny has a huge number of appearances, and it does not "want" to fit into the Procrustean bed of philosophical definitions". In this regard, the researcher of the problems of comism and laughter V. Propp (1895-1970), proposes to determine the specifics of the comical "in each separate case" ${ }^{\prime 8}$. And if such a proposal is perceived completely calmly within the framework of cultural studies and art history, then it sometimes provokes a negative attitude among philosophers who prefer the deductive method. Against the problem of the comical as philosophical discourse are also such qualities of laughter as uncontrollability, irrationality, polysemantism and contradictory?

Speaking about the antinomy of the philosophical discourse of laughter, we note that back in antiquity there were "two largely opposite systems of views on laughter" ${ }^{\prime 10}$. One of them, presented by Democritus, Aristophanes, and Lucian, offers the consideration of laughter in the broadest sense as a "whole worldview", a form of critical reflection that makes it possible to distinguish genuine being from non-being, visible from essential, etc. Another tradition, founded by Plato and Aristotle, is engaged in the search for the essence of laughter as a concrete manifestation of human nature. It seems to us (and we will try to justify this) that I. Kant's theory of laughter cannot be contained within the framework of any one of these traditions. Culture of the 18th century favored both the first and second approaches. A well-known scholar of the philosophy of humor, Lydia Amir, believes that it is from the eighteenth century, philosophers began to pay much more attention to the phenomenon of laughter than it was before ${ }^{12}$.

In particular, in Shaftesbury's philosophy, L. Amir finds not only provisions on the causes of laughter, but also arguments about the role of laughter as an important means of cognitive activity ("important

6 Карасев Л.В. Философия смеха. URL: http://teologia.ru/www/biblioteka/esthetika/ karasev.htm (дата звернення: 10.10.2019).

7 Жан-Поль Приготовительная школа эстетики. Вступ. статья, сост., пер. и коммент. Ал. В. Михайлова. М.: Искусство, 1981. С. 128.

${ }^{8}$ Пропп В.Я. Проблемы комизма и смеха. Ритуальный смех в фольклоре (по поводу сказки о Несмеяне). М.: Лабиринт, 1999. URL: https://www.gumer.info/bibliotek_Buks/ Culture/propp/02.php (дата звернення: 1.10.2019).

${ }^{9}$ Amir L. Op. cit., p. 2.

10 Сычев А.А. Природа смеха или Философия комического. Саранск: Изд-во Мордовского ун-та, 2003. С. 23.

${ }^{11}$ Ibid.

${ }^{12}$ Amir L. Op. cit., p. 3. 
epistemological tools that promote truth and rationality") ${ }^{13}$. Like Shaftesbury, Kant, on the one hand, is trying to understand the nature of laughter, and on the other, he is not alien to a broader view of laughter as a kind of reflection.

The achievements of I. Kant within the first direction are better visible against the background of the modern classification of theories of the comical. D.H. Monro (1911-2001) in his book The Argument of Laughter "sorted ... individual theories into three categories, corresponding to three basic views about humor. ... we shall call these the Superiority Theory, the Incongruity Theory, and the Relief Theory"14. The first (at the time of occurrence) - the Superiority Theory - unites philosophers who note in laughter, on the one hand, the subject's sense of pleasure associated with a positive experience of his superiority, and on the other, a mockery of a loser. "... the pleasure we take in humor derives from our feeling of superiority over those we laugh at. According to this view, all humor is derisive" ${ }^{15}$. The basis of this theory is attributed to Plato (Adrian Bardon) and/or Thomas Hobbes (D.H. Monro).

The second laughter paradigm - the Incongruity Theory - dates back to Aristotle, the author of a classical definition that has not lost its significance within the framework of the contemporary philosophical discourse: "the ridiculous is only a part of the ugly ... some mistake, ugliness, but painless and harmless"16. Rejoicing in the comedy, we laugh at ugliness, if that ugliness is not painful or destructive to us. Aristotle not only determines the measure of evil or ugliness, which is the subject of laughter, but also clearly indicates the type and genre of cultural practices within which such a phenomenon of "harmless evil" can be ridiculous - theatrical comedy. Thus, he suppresses possible objections as to the fact that in life there are many situations of incongruity that are not at all funny.

Laying the foundation of the Incongruity Theory, Aristotle points to laughter as a result of correlating disparate things: "the gods ... seem ridiculous if they relate to us" ${ }^{\prime 17}$. Thus the philosopher not just emphasizes a certain kind of Incongruity, but names the maximum possible discrepancy between the earthly and the divine, the profane and the sacred. The incongruity factor recorded by Aristotle finds its development in the philosophy of F. Hutcheson (1694-1747). It seems to us that the Scottish philosopher criticizes Thomas Hobbes'

\footnotetext{
${ }^{13}$ Amir L. Op. cit., p. 4.

14 Bardon A. The Philosophy of Humor. URL: https://www.academia.edu/9819670/ The_Philosophy_of_Humor (дата звернення: 4.01.2018).

${ }_{15}$ Monro D.H. Theories of Humor. Writing and Reading Across the Curriculum 3rd ed. Laurence Behrens and Leonard J. Rosen, eds. Glenview, IL: Scott, Foresman and Company. 1988. P. 349-355. URL: https://msu.edu/ jdowell/monro.html (дата звернення: 4.06.19).

${ }^{16}$ Aristotle. The Poetics. 1448 a, 33-34.

${ }^{17}$ Aristotle. The Poetics. 1101b, 20.
} 
Superiority Theory, primarily on the basis of axiological considerations. If laughter expresses a sense of superiority over a loser, then laughter in the optics of a Christian worldview is a sinful phenomenon, and it is completely unworthy of a Christian to laugh. As will be seen from the foregoing, similar considerations at one time prevented Kant from appreciating the positive contribution of the Superiority Theory to the philosophy of laughter.

The third paradigm - the Relief Theory - considers laughter as a mechanism for "relieving" tension or suppressing, crowding out negative emotions. The founders of this theory, as a rule, are called G. Spencer and Z. Freud. However, L. Amir in her book "Humor and the good life in modern philosophy ..." shows that Anthony Ashley Cooper, 3rd Earl of Shaftesbury (1671-1713) also proposed a view of laughter as a form of liberation ${ }^{18}$. It is impossible to prove that these views of Shaftesbury somehow influenced Kant's point of view. But the possibility of reading Kant in the spirit of the Relief Theory, as will be shown by the example of the interpretation of his quotes, should not be rejected.

Since we are in some way deconstructing the common critical notion of I. Kant's laugh (using "soft, post-post-modern deconstruction" as opposed to its post-modern versions), we cite completely in the original language those quotes that, from our point of view, can not be unambiguously interpreted in the spirit of prevailing views.

\section{Kant's theory of laughter}

Kant's theory of laughter is usually considered as an "afterthought of Kant's aesthetics"19. The researchers either stress the "underlined optionalness" of Kant's theoretical interest in laughter ${ }^{20}$ or write about a disappointingly small space of text occupied by the relevant subject ${ }^{21}$. Paul Carus makes even more negative statement on the topic: "Kant's theory of ridiculous is interesting but unsatisfactory" 22 . Are we really dealing with a

${ }^{18}$ Столяр М. Філософія сміху і гумору в сучасному історико-філософському дискурсі. Огляд книги: Amir, L. (2014). Humor and the Good Life in Modern Philosophy: Shaftesbury, Hamann, Kierkegaard. Albany: State University of New York Press. Sententiae 37:1 (2018) C. 171 .

${ }^{19}$ Giamario P.T. "Making reason think more" (laughter in Kant's aesthetic philosophy). URL: https://www.academia.edu/35344281/Making_Reason_Think_More_Laughter_in_Kants_ Aesthetic_Philosophy (дата звернення: 4.01.2020).

${ }^{20}$ Куприянов В.А. Место смеха в системе философии Гегеля и его отношение к идеалу в контексте искусства. URL: http://anthropology.ru/ru/text/kupriyanov-va/mesto-smeha-vsisteme-filosofii-gegelya-i-ego-otnoshenie-k-idealu-v-kontekste (дата звернення: 5.01.2020).

21 Straus I.J. Incongruity Theory and the Explanatory Limits of Reason. URL: https://scholarworks.uvm.edu/hcoltheses/26/ (дата звернення: 9.01.2020).

${ }^{22}$ Carus P. On the philosophy of laughing. The Monist. 1998. Vol. 8. № 2. P. 255. 
question that is on the periphery of Kant's philosophy? And can this topic be considered as basically exhausted in the already existing generalizations and characteristics (positive or negative)?

The purpose of this work is to analyze Kant's theory of laughter from the point of view of the possibilities of its interpretation that have not yet been disclosed, as well as explication of philosophical irony in connection with the critical methodology of the thinker. We will discuss the philosophical irony of Kant as an important means of attaining a certain super-task of critical philosophizing in the second part of the article. Let us start with the material that directly concerns the topic of laughter.

Literature review. Kant's understanding of the phenomenon of laughter in one degree or another is the subject of attention of such researchers as A. Bardon, P. Carus, Patrick T. Giamario, V. Kupriyanov, J. Morreall, D.H. Monro, A. Smuts, A. Chuprov and others. As a rule, Kant is considered a representative of the Incongruity Theory. According to D.H. Monro, Kant was the first to formulate the corresponding definition of laughter: "Incongruity is often identified with "frustrated expectation", a concept we owe to Immanuel Kant (1724-1804), who says that "humour arises from the sudden transformation of a strained expectation into nothing"23. A. Bardon writes about Kant's version of the Incongruity Theory as its specific instance: "The Incongruity Theory has been embraced in different forms by Hutcheson, Immanuel Kant, Arthur Schopenhauer, Søren Kierkegaard, and Luigi Pirandello"24. A. Sychov considers Kant to be an adherent of the Incongruity Theory, writing about it in the historical and philosophical part of his monograph "The Nature of Laughter, or the Philosophy of the Comical" "25. A. Smuts also refers to Kant as a representative of the Incongruity Theory: "In the Critique of Judgment, Immanuel Kant gives a clearer statement of the role of incongruity in humour..."26. We will try to understand how fully this viewpoint describes Kant's position on the phenomenon of laughter.

It is true that the phenomenon of contrast as a cause of laughter (or merry disposition of the spirit) is highlighted by the philosopher in several formulations and examples. For instance, Kant defines humour as "...the talent of being able voluntarily to put oneself into a certain mental disposition, in which everything is judged quite differently from the ordinary method (reversed, in fact), and yet in accordance with certain rational principles in

\footnotetext{
${ }^{23}$ Monro, D.H. Op. cit.

${ }^{24}$ Bardon, A. Op. cit.

${ }^{25}$ Сычев А.A. Op. cit. C. 29.

${ }^{26}$ Smuts A. Humor. Internet Encyclopedia of Philosophy. URL: https://www.iep.utm.edu/ humor/ (дата звернення: 11.01.2020).
} 
such a frame of mind" 27 ["Laune im guten Verstande bedeutet nämlich das Talent, sich willkürlich in eine gewisse Gemütsdisposition versetzen zu können, in der alle Dinge ganz anders als gewöhnlich (sogar umgekehrt) beurteilt werden"] ${ }^{28}$. Kant writes that laughter is induced "by means of contrast" ("a contrast that excites a laugh") ${ }^{29}$ ["vermittelst eines Lachen erregenden Kontrastes" ${ }^{\prime 3}$. That is, the cause of laughter atmosphere is the discrepancy between what we are ready to hear because of rational inertia of thought and a completely unexpected, witty judgment. For example, Kant calls the reason for table fun a contrast between rational judgments and fooling around. Kant writes, "In everything that is to excite a lively convulsive laugh there must be something absurd" 31 ["Es muss in allem, was ein lebhaftes erschütterndes Lachen erregen soll, etwas Widersinniges sein"32. Then "there may be a great deal of gossip at the feast, but no one will be answerable for what he says, because they are only concerned with momentary entertainment, and not with any permanent material for reflection or subsequent discussion" ${ }^{33}$ [“....manches kann ins Gelage hinein geschwatzt werden, und niemand über das, was er spricht, verantwortlich sein will"' ${ }^{34}$.

Note that Kant not only indicates inconsistency as a cause of laughter, but also clarifies which inconsistencies are laughable. It is no secret that not all contrasts are perceived with laughter. On the contrary, most of them plunge us into completely different states: surprise, irritation, annoyance, anger, fear, etc. The Incongruity Theory gives a rather abstract explanation of the phenomenon of laughter, which needs clarification. Kant points to the specific form that determines the laughter orientation of communication. This form is the entertainment genre of communication.

However, an attempt to clarify the peculiarities of the laughter incongruity leads us to a deadlock of a tautological definition: laughter arises because of the contrast within the genre that is a priori oriented to laughter. The question of what makes this genre laughter-oriented remains open. Nevertheless, we can say that Kant - if we consider him an adherent of the Incongruity

${ }^{27}$ Kant's Critique of Judgement, translated with Introduction and Notes by J.H. Bernard (2nd ed. revised). London: Macmillan. URL: http://oll.libertyfund.org/titles/kant-the-critique-ofjudgement (дата звернення: 7.05.2019).

${ }^{28}$ Kant, I. Kritik der Urteilskraft. Fünfte auflage. Herausgegeben, eingeleitet und mit einem personen - und sachregister versehen von Karl Vorländer. Leipzig: Verlag von Felix Meiner, 1922. S. 194

${ }^{29}$ Kant's Critique of Judgement... Op. cit.

${ }^{30}$ Kant, I. Kritik der Urteilskraft... S. 194.

${ }^{31}$ Kant's Critique of Judgement... Op. cit.

${ }^{32}$ Kant, I. Kritik der Urteilskraft... S. 190

${ }^{33}$ Kant's Critique of Judgement... Op. cit.

${ }^{34}$ Kant, I. Kritik der Urteilskraft... S. 158. 
Theory - went further than his colleagues, who limited themselves to stating the existence of contrast itself. Kant points not only to the fact of incongruence, but also to its cultural context.

The Incongruity Theory can be illustrated by the following anecdote about mourners. A certain heir complains that he is unable to create the right atmosphere at the funeral of a rich relative: "the more money I give my mourners to look sad, the more cheerful they look!"35 [“je mehr ich meinen Trauerleuten Geld gebe, betrübt auszusehen, desto lustiger sehen sie aus!"' ${ }^{36}$. The relative who pays the mourners, expects from them a "high-quality" performance of grief, but causes involuntary joy to people who have earned good money. Here, a laughing person reacts to the contrast of grief and joy.

The atmosphere of table talk of friends initially implies a cheerful mood, and it contributes to the birth of absurd utterances, since it removes responsibility from the person for the degree of rationality of his words. In this case, the control of reason is removed twice - in the semantics of the utterances and in the genre of the cultural practices. Temporary dismissal of reason as a cause of laughter is a new turn of thought within Kant's theory. Later A. Schopenhauer would develop this aspect of the Incongruity Theory. However, according to Ian Jaeger Straus, "Schopenhauer improves Kant's account by focusing less on absurdity and frustrated expectations, instead suggesting that amusement is caused by incongruities between individual perceptions and conceptual abstractions" ${ }^{\text {37 }}$.

Most often, the commitment of Kant to the Incongruity Theory is proved by the following quotation: "Laughter is an affection arising from the sudden transformation of a strained expectation into nothing"38 ["Das Lachen ist ein Affekt aus der plötzlichen Verwandlung einer gespannten Erwartung in nichts"] ${ }^{39}$. It seems to us that the semantics of this statement can be interpreted differently. Some authors one way or another suggest this possibility in their comments. For example, L. Olin writes that the Incongruity Theory "is usually credited to Kant" ${ }^{40}$. The phrase "is credited to Kant" not just indicates a widespread point of view, but also hints at the possibility of other interpretations. In particular, Ian Jaeger Straus writes, "There is some ambiguity as to what precisely Kant means by the "transformation of a strained expectation into nothing" ${ }^{\text {"41 }}$. Because if we are talking about contrast

\footnotetext{
${ }^{35}$ Kant's Critique of Judgement... Op. cit.

${ }^{36}$ Kant, I. Kritik der Urteilskraft... S. 191.

${ }^{37}$ Straus, I.J. Op. cit.

${ }^{38}$ Kant's Critique of Judgement... Op. cit.

${ }^{39}$ Kant, I. Kritik der Urteilskraft... S. 190.

${ }^{40}$ Olin, L. Op. cit. P. 343

${ }^{41}$ Straus, I.J. Op. cit.
} 
in the semantic plane, then we mean the maximally pronounced difference of meanings, but not the relation of meaning to nonsense. It means that the contrast is described by the formula for transition of one something into another something. The latter may be opposite to the former, or may switch the original direction of thought into an unexpected register of meanings. However, it would be a different something, not nothing. But Kant uses the word "nothing" ("nichts"). Therefore, he speaks about the disappearance, dissolution, annihilation...

If the meaning does not disappear, just changes dramatically, what then disappears? The answer is that disappears the "strained expectation", with which the outcome is expected. In this regard, A. Chuprov remarks, "As a rule, Kant is considered to be an adherent of the Incongruity Theory... But I would like to draw attention not only to the statement of the incongruity... but also to a person's ability to annihilate his/her own strained expectation through laughter. In essence, Kant speaks about laughter as a means of liberation...” [“Как правило, Канта относят к сторонникам теории несоответствия... Но хотелось бы обратить внимание не только на констатацию несоответствия... но и на способность человека посредством смеха уничтожить собственное напряжённое ожидание. В сущности, Кант говорит о смехе как способе освобождения...”] $]^{42}$.

Generally speaking, Kant's "something-to-nothing" transformation algorithm almost perfectly describes the laughter practices of hoax or practical joke, despite the fact that for Kant, hoax is not a subject of research as a specific laughter form. The practices of hoax imply the dissolution of fear, fright, and awkwardness. They really turn into nothing. If the meaning of turning "something into nothing" is the transformation of tension into nothing, that is, the transition to relief, then the corresponding words of Kant can be interpreted in the plane of the Relief Theory. It is possible to consider the Relief Theory as a relatively independent paradigm of the philosophy of laughter, and it is equally possible to view it as a special case of the Incongruity Theory. In any case, the incongruity is complemented by another aspect of laughter.

However, Kant's philosophy of laughter is not limited to these two paradigms. Telling a story about a Hindu amazement about the effervescent drink escaping from the bottle, Kant says: "At this story we laugh, and it gives us hearty pleasure; not because we deem ourselves cleverer than this ignorant man, or because of anything else in it that we note as satisfactory to the

42 Чупров А. Смех как атрибут человека. Топос: литературный и философский журнал. 2018. URL: http://www.topos.ru/article/ontologicheskie-progulki/smeh-kak-atributcheloveka. (дата звернення: 22.01.18). 
Understanding, but because our expectation was strained [for a time] and then was suddenly dissipated into nothing"43 ["so lachen wir nicht, weil wir uns etwa klüger finden als diesen Unwissenden, sondern unsere Erwartung war gespannt, und verschwindet plötzlich in nichts" ${ }^{\prime 4}$.

Let us remind: an Englishman asked the Hindu, what surprised him when the beer shot out. The latter answered: "I am not at all astonished that it should flow out, but I do wonder how you ever got it in" mich auch nicht darüber, dass es herausgeht, sondern wie ihr's habt hereinkriegen können" 46 .

As we see, the philosopher in this case categorically denies the phenomenon of mockery and, accordingly, the explanatory potential of the Superiority Theory. However, it seems to us that he is not doing it consistently enough. After all, what gave the Englishman "the hearty pleasure", if not the childish naiveté of the Hindu who amuses by his spontaneity and ignorance? And where, is in this case, is the transformation of suspense "into nothing"?! The straining of curiosity is indeed present, because the European faces a different culture and perception. But what than is the odious "nothing"?

Doubtlessly, there is a contrast here. However, it is not a laughter contrast. Kant describes the detected discrepancy as follows: “....and behold! it is the unspoiled innocent nature which we do not expect to find" 47 ["und siehe! es ist die unverdorbene schuldlose Natur, die man anzutreffen gar nicht gewärtig hat" ${ }^{\prime 8}$. But does this discrepancy cause laughter? Rather, liking or even respect: "...the fact that something infinitely better than all assumed manner, viz. purity of disposition (or at least the tendency thereto), is not quite extinguished yet in human nature, blends seriousness and high esteem with this play of the Judgement (highlighted by us - M.S.)" "49 ["Dass aber etwas, was unendlich besser als alle angenommenen Sitten ist, die Lauterkeit der Denkungsart, doch nicht ganz in der menschlichen Natur erloschen ist, mischt Ernst und Hochschätzung in dieses Spiel der Urteilskraft" ${ }^{\text {"50. }}$.

Then what caused laughter? Was not it the feeling opposite to respect - the feeling of superiority of civilized people over the "native"? Even if in this case we see a good-natured laughter, as adults laugh at the words of a naive child, it is still a patronizing laughter. If anything was turned into "nothing", it

\footnotetext{
${ }^{43}$ Kant's Critique of Judgement... Op. cit.

${ }^{44}$ Kant, I. Kritik der Urteilskraft... S. 191.

${ }^{45}$ Kant's Critique of Judgement... Op. cit.

${ }^{46}$ Kant, I. Kritik der Urteilskraft... S. 191.

${ }^{47}$ Kant's Critique of Judgement... Op. cit.

${ }^{48}$ Kant, I. Kritik der Urteilskraft... S. 193.

${ }^{49}$ Kant's Critique of Judgement... Op. cit.

${ }^{50}$ Kant, I. Kritik der Urteilskraft... S. 193.
} 
was the hint of conscience about the existence of something "infinitely better"51 ["unendlich Besseres"... 52 But the political instinct of cultural superiority drowned out the faint promise of conscience, and restored the status quo of civilized people, who, in the depth of their souls, consider themselves to be much higher than the "wild people". Then why in this case does Kant not reflect over such an obvious element of ridicule?

If a person of such a deep analytical mind "does not see" a certain spectrum of laughter, than the existence of a corresponding "blind spot" needs to be explained. It seems to us that this is possible, given the factor of the deepest impact of Kant's moral consciousness on his philosophical thinking. In this case, the impact is negative. It turns out that Kant not only did not consider it possible to laugh at another person because of the immorality of ridicule (which undoubtedly deserves respect), but also for some time even failed to notice the inclination to such laughter inherent in himself, as in any other person. In Kant's interpretation of the anecdote, told by the Englishman, the philosopher's moralism turned into the magnifying glass that hid the presence of a sense of superiority the laughter. This example shows: in the cases when philosopher's "a priori" prescription distorts the perception of the phenomenon under consideration, one should pay attention not only to the "cataphatic" (affirming) part of the utterance, but also to the "apophatic" (negating) optics with the appropriate correction for possible distortion.

In principle, we can assume that, consciously or unconsciously, Kant included in his theory almost all the main kinds of laughter (relief laughter, intellectual laughter about the original switching of semantics, and mocking laughter). Accordingly, he laid the foundations for various theoretical positions as complementary. Among others, Kant had proposed a new, not yet formed in that time theory - the Relief Theory. On the basis of his thoughts, $\mathrm{H}$. Spenser would later suggest that "laughter is a result of the pleasure we take in escaping from the restraint of grave feelings" "53, a statement, which became a foundation of the Relief Theory.

In addition to the already mentioned paradigms, we find in the "Critique" another very important stroke to portrait of the fourth (conditionally fourth) paradigm. Kant speaks about laughter as a kind of play of Judgement ["dieses Spiel der Urteilskraft" ${ }^{54}$. We enjoy laughter because, according to Kant, "our own blunder in some kind of... subject indifferent for us ... we throw some

${ }^{51}$ Kant's Critique of Judgement... Op. cit.

${ }^{52}$ Kant, I. Kritik der Urteilskraft... S. 193.

53 Spencer H. Essays: Scientific, Political and Speculative. 1854. Vol. 2. URL: https://oll.libertyfund.org/titles/spencer-essays-scientific-political-and-speculative-vol-2 (дата звернення: 15.01.18)

${ }^{54}$ Kant, I. Kritik der Urteilskraft... S. 193. 
more time, like a ball, to and fro" "55 ["weil wir unseren eignen Missgriff nach einem für uns übrigens gleichgültigen Gegenstande, ... wie einen Ball, noch eine Zeitlang hin- und herschlagen"

Kant points out that a change in the states of tension and relaxation occurring in this case, is "conducive to health",57 ["eine zur Gesundheit gereichende Motion"] ${ }^{58}$. This again confirms the proximity of the philosopher to the position of the Relief Theory. Therefore, as we see, Kant foreshadows not only the connection between the Incongruity Theory and the Relief Theory, but also between them and the game theory of laughter. The explanatory potential of the game concept suits Kant also because game combines perfectly with that good-hearted laugh ["mit einem solchen gutherzigen Lachen"59, which does not contradict the philosopher's strict morality. From a rational point of view, this game is ambivalent. On the one hand, it doesn't think of anything, and on the other, "it is judged on all things ... nevertheless, according to certain principles of reason" 60 ["alle Dinge werden ... doch nach gewissen Vernunftprinzipien... beurteilt" ${ }^{61}$. That is, laughter is caused by the game of rationality in a situation of reduction of objectivity of the mind. Kant here clarifies his thoughts on the "resting of the reason", expressed in the "Critique". The reason rests, but does not turn off completely, since the forms of rationality are not removable even in the most absurd utterances. A similar thought regarding laughter as a result of a special, objectless game, we find in H. Bergson's work "Laughter": "...But to detach oneself from things and yet continue to perceive images, to break away from logic and yet continue to string together ideas, is to indulge in play..., ${ }^{\circ 2}$.

All these observation directly lead us to the contemporary, heterogeneous theory of laughter, according to which there is no single laughter, but there are ontologically different "laughters" ["смехи"] ${ }^{63}$, each of them having its own explanation. Such an understanding suggests a rather rare in philosophical discourse cumulative approach to all the methodological findings in the

${ }^{55}$ Kant's Critique of Judgement... Op. cit.

${ }^{56}$ Kant, I. Kritik der Urteilskraft... S. 191.

${ }^{57}$ Kant's Critique of Judgement... Op. cit.

${ }^{58}$ Kant, I. Kritik der Urteilskraft... S. 192.

${ }^{59}$ Kant, I. Kritik der Urteilskraft... S. 194.

${ }^{60}$ Kant's Critique of Judgement... Op. cit.

${ }^{61}$ Kant, I. Kritik der Urteilskraft... S. 194.

62 Bergson, $\mathrm{H}$. Laughter: An essay on the meaning of the comic. URL: https://www.templeofearth.com/books/laughter.pdf (дата звернення: 18.02.18).

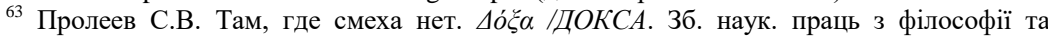
філології. Вип. 13. Сміх та серйозність: множинність видів та взаємин. - Одеса: Видавництво Одеського національного університету, 2008. С. 29. 
history of laughter studies. It also determines the need for interparadigm study of the laughter culture ${ }^{64}$.

Another point that needs to be taken into account when speaking of I. Kant's theory of laughter: his position is not static. The philosopher specifies, and sometimes significantly changes his opinion, if we compare the content of the "Critique of Judgment" (1790) and "Anthropology from a pragmatic point of view" (1798). In the first work, the concept of laughter occurs about ten times. In addition, in "Anthropology" we find more detailed fragments, which number almost three times more. Moreover, the point is not only in the number of statements, but also in the degree of development of the topic.

First of all, in "Anthropology", arguments in favour of the incongruence factor as a cause of laughter are closely intertwined with the optics of discourse of mockery: "It is not advisable to praise a person too highly in advance when we wish to introduce him to others for the first time; it might rather be a malicious trick on the part of a rogue to make a person seem ridiculous. ... But if what was praised in advance turns out to be just the opposite of what we were led to anticipate, then the object portrayed, provided it is otherwise innocuous, arouses the greatest laughter" 65 ["Es ist nicht ratsam, von einer Person, die man zuerst in eine Gesellschaft einführen will, vorher viel Hochpreisen zu machen; vielmehr kann es oft ein boshaftes Stückchen von einem Schalk sein, jene lächerlich zu machen). Ist nun aber das vorher Gepriesene gar das gerade Widerspiel von dem, worauf die Erwartung gespannt war, so erregt der aufgeführte Gegenstand, wenn er sonst unschädlich ist, das größte Gelächter"' ${ }^{66}$.

As we can see, Kant confirms his preference for the concept of contrast (or relief?). But, unlike the previous book, he does not any longer deny the semantics of mockery. Moreover, the philosopher classifies the various laughter situations, described in the discourse of ridicule. He names four such situations. The first two are associated with laughing at people, who are armed with a sense of humour and can respond in kind. This is laughter on equal position that is using a person in one's company as a butt for witty remarks (pull his leg) "without being cutting" ["Spott ohne Anzüglichkeit"] ${ }^{67}$. Kant

64 Stoliar M., Stechenko T. The discourse of the laughter theory in the optics of Postpositivism and Postmodernism. Gileya: Scientific journal. Collection of scientific works. Kyiv: VIP UAE, 2018. 131 (4). P. 319.

${ }^{65}$ Kant I. Anthropology from a Pragmatic Point of View. 1996. URL: https://books.google.com.ua/books?id=TbkVBMKz418C\&printsec=frontcover\&hl=ru\#v=onepag $\mathrm{e} \& \mathrm{q} \& \mathrm{f}=$ false (дата звернення: 10.05.2019).

66 Kant I. Anthropologie in pragmatischer Hinsicht. Fünfte Auflage. Herausgegebe, eingeleitet und mit Personen- und Sachregister versehen von Karl Vorländer. Der Philosophischen Bibliothek. Leipzig: Verlag von Felix Meiner. 1912. S. 74-75.

${ }^{67}$ Kant, I. Op. cit. S. 202. 
sees such a laughter as a good-natured cultural entertainment ["eine gutmütige und zugleich kultivierende Belebung" ${ }^{68}$.

The third situation implies laughter at a simpleton, who cannot answer in the like because of his low level of either intellect or general culture. Appraisal of such laughter, according to Kant, can vary within the limits from indelicacy to maliciousness. The fourth situation is laughter at a dependent person, a sponger, who for a bit of indulgence allows himself to be made a fool of. This kind of mockery Kant considers to be "an evidence of bad taste and also evidence of the callous moral feeling of those who can laugh about this till their sides split"69 [Anthropology] [“...vom schlechten Geschmack sowohl als stumpfen moralischen Gefühl derer, die darüber aus vollem Halse lachen können" ${ }^{\text {"70 }}$.

Besides such reasons for laughter as incongruity and surprise, the philosopher also mentions harmlessness of event ["wenn er unschädlich ist"] $^{71}$. This last factor in the theory of laughter was not new in Kant's times. It was singled out by Aristotle: "the ridiculous is only a part of the ugly ...

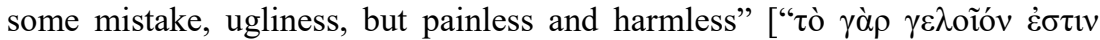

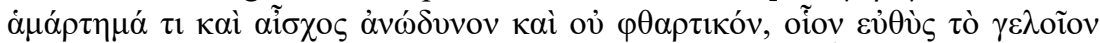

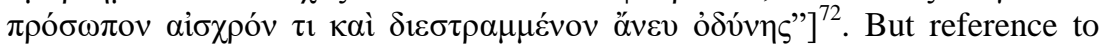
thoughts of predecessors and colleagues was not among the stylistic merits of the philosophical literature of the said period. It is especially true when it comes to the philosophy of Kant - a kind of Baconian spider, which draws the thread of the reasoning from the depth of his own mind.

In "Anthropology" Kant gives a classification of types of laughter. $\mathrm{He}$ does not only distinguishes physiological, moral, ethical, communicative and intellectual types. Every kind of laughter has ambivalent projections. If in the "Critique" Kant wrote about laughter as a mechanism, conductive to health, then in "Anthropology" he already differentiates the laughter which favourably affects the organism, and the laughter that indicates a morbid condition of a person. Excessive gaiety, witticisms and loud laughter Kant qualifies as one of the symptoms of hypochondria ["Grillenkrankheit (Hypochondrie)"'] ${ }^{73}$.

In addition to physical health, for Kant an important role is played by the factor of moral well-being, which is present in morally sound laughter. In this plane, laughter is divided into two types - morally justified and unacceptable

\footnotetext{
${ }^{68}$ Kant, I. Ibid.

${ }^{69}$ Kant, I. (1996). Anthropology.

${ }^{70}$ Kant, I. (1912). Anthropologie... S. 202.

${ }^{71}$ Kant, I. (1912). Anthropologie... S. 75.

${ }^{72}$ Aristotle. The Poetics. 1449a, 35-37.

${ }^{73}$ Kant, I. (1912). Anthropologie... S. 128-129.
} 
(rude, degrading). The philosopher recognizes the possible use of laughter as a light (play) weapon only against those who have a good command of this weapon. In the communicative plane, laughter is considered either as a factor contributing to communication, or vice versa - making such communication impossible: "Good-natured (openhearted) laughter (which belongs to the emotion of joyfulness) is sociable; malicious (sneering) laughter is hostile",74 ["Das gutmütige (offenherzige) Lachen ist (als zum Affekt der Fröhlichkeit gehörend) gesellig, das hämische (Grinsen) feindselig"75.

Lastly, Kant clarifies his position as to the intellectual value of laughter. If in "Critique" according to Kant, the laughter only imitates rationality, in "Anthropology" Kant emphasizes the intellectual abilities, involved in the laughter practices. He distinguishes between the laughter of an intellectual and a person, intellectually challenged. Laughter of an intelligent person is enjoyable, amusing and invigorating pastime where "intelligence concentrates on marking the identity within the manifold as to partial differences",76 [Anthropology]. ["Es ist angenehm, beliebt und aufmunternd, Ähnlichkeiten unter ungleichartigen Dingen aufzufinden und so, was der Witz tut, für den Verstand Stoff zu geben, um seine Begriffe allgemein zu machen" [нем, S. 140-141]. If "the faculty of discovering the particular for the universal" ["So wie das Vermögen zum Allgemeinen das Besonderen auszufinden"] Kant qualifies as the ability of judgment, then "faculty of discovering the universal for the particular is called intelligence" ["...so ist dasjenige zum Besonderen das Allgemeine auszudenken, ist der Witz (Ingenium)",77.

As can be seen from the above, a distance of eight years deepened the philosopher's interest in the topic and enriched the corresponding discourse with new approaches. Within the 3rd "Critique", Kant leans towards The Incongruity Theory, but simultaneously unmanifestly explicates the Superiority Theory (that he criticizes), and draws attention to the moment of change of stress and relief, which plays the role of a central factor in The Relief Theory paradigm. In "Anthropology" Kant continues to develop the philosophy of laughter simultaneously in several paradigm directions. Here he rejects the criticism of the Superiority Theory in favour of its clarification and development. Therefore, we can speak of Kant as the founder of the polyparadigm theory and the forerunner of the contemporary heterogeneous understanding of the phenomenon of laughter.

\footnotetext{
${ }^{74}$ Kant, I. (1996). Anthropology...

${ }^{75}$ Kant, I. (1912). Anthropologie... S. 201.

${ }^{76}$ Kant, I. (1996). Anthropology...

${ }^{77}$ Kant I. Anthropologie ... S. 113
} 


\section{Immanuel Kant's theory philosophical irony}

However, the meaning of Kant's understanding, as we see it, cannot be reduced to the semantics of fragments, immediately related to the concept of laughter or humour. In particular, the researcher Patrick T. Giamario draws attention to the transcendental dimension of laughter in Kant's critical thinking: "laughter is the transcendental condition of possibility for both the beautiful and the sublime"78. He states that "laughter in fact constitutes the most basic aesthetic judgment in Kant" and "Kantian critical philosophy is itself a philosophy of laughter"79. In this context, we would like to draw attention to the laughter aspect of Kant's critical methodology.

In the preface to the second edition of "Critique of Pure Reason" the philosopher writes words that are widely cited in monographs, articles and university textbooks on philosophy: "I had to limit knowledge in order to make room for faith" ("Ich musste also das Wissen aufheben, um zum Glauben Platz zu bekommen").

It is clear, that Kant did not wish to eliminate knowledge in favour of the faith $^{80}$. But what exactly does he mean? Does he speak of the abolition (aufheben) of "semblant knowledge" ${ }^{\text {? }}$ ? Or does Kant explain this limitation by the need to "take away" from speculative reason its "claim to transcendental knowledge" in order to "allow the existence of God, freedom and immortality" ${ }^{\prime 2}$. Or he means transference or replacement, that is, finding a more adequate position for what is being transferred and for what is being put in its place (exactly this version of the translation of the verb "aufheben" is considered correct both in relation to the culture of the XVIII century and in the context of works of Kant).

N. Motroshilova explains this quotation in the following way: "The whole thing for Kant is that knowledge occupied not only its rightful place, but also, in the form of, for example, rational theology, tried to usurp for itself that additional space that should be occupied by faith only" ${ }^{\prime 3}$. It means that

${ }^{78}$ Giamario P.T. "Making reason think more" (laughter in Kant's aesthetic philosophy). 2017. P. 161-176. URL: http://www.tandfonline.com/doi/abs/10.1080/0969725X.2017.1406055? journalCode=cang2 (дата звернення: 9.03.2019).

${ }^{79}$ Ibid.

${ }^{80}$ Ойзерман Т.И. К вопросу о знаменитом тезисе Канта: “...мне пришлось ограничить (aufheben) знание, чтобы освободить место вере...”. URL: http://kant-online.ru/wpcontent/uploads/2014/06/Full.pdf (дата звернення: 10.06.2019).

${ }^{81}$ Ibid.

82 Батракова И.А. Отношение знания и веры в критической философии Канта. URL: http://www.smyrnyh.com/?page_id=392 (дата звернення: 10.06.2019).

83 Мотрошилова Н.В. Отношение знания и веры в "Критике чистого разума" Иммануила Канта. Материалы Междунар. научн. конференции "Проблема веры и знания в немецкой классической философии”. СПб.: Изд-во С.-Петерб. ун-та, 2008. URL: 
knowledge in itself is not semblant. Knowledge is made semblant by its sacralised status. Kant reveals the meaning of "transference" by the need to "take away" from the speculative mind its "claims to transcendental knowledge", and return the place, usurped by reason, to faith (more morallyreligious than purely religious).

E. Solovyiov reminds that Kant "once called his teaching "a genuine Enlightenment". Its essence (unlike "the naïve Enlightenment") he saw in not only wresting a person from the grip of traditional superstitions, but also freeing him from superstitious hopes of the power of theoretical reason..."84. Kant contrasts a new religious faith - faith in science and unlimited human cognitive abilities - to rationally grounded, positive, pragmatic scepticism, and to what he considers a true faith. In place of the pseudo-sacred, he wants to restore the truly sacred. That is, it can be said that Kant carries out the desacralization of the speculative mind.

If in the Enlightenment ideology human reason claims the supreme place in being, and Kant by rational means, demonstrating the highest level of this reason, nonetheless, refutes such a claim, then what kind of conflict arises, and how does it relate to the laughter culture? As we see it, the connection is immediate. We are dealing with the classical (existing since Socrates' times) philosophical irony. Kant does not just accept the rules of the game, but complicates them to the utmost, demonstrating a fundamentally new level of philosophical discourse. But he does not accept the Enlighters' belief that deifies reason. Kant brings intellectual "technologies" to the unprecedented perfection. And then it turns out that all this was done in order to lead the arrogant reason into an antinomic deadlock... "This is a kind of mockery or flout, containing a very ... deliberate thought... for the sake of higher objective goals" - wrote about Socrates' irony Russian philosopher A. Losev ${ }^{85}$. We think that Losev's thought can be applied not only to Socrates, but also to Kant.

It is not Kant's tragedy, that his attempt of warning and preventing the spread of essentially ideological practices of sacralisation was unsuccessful. It is the tragedy of those who later fell victim to these practices in their authoritarian (and still later - totalitarian) varieties. The philosopher was too ahead of his time. The religion of reason at that time was very young, and it had not yet beget all its "children" - Hegelian absolutism, revolutionary

\footnotetext{
https://www.rhga.ru/science/conferences/rusm/russian_thought/vera_i_znanie.php

(дата звернення: 28.12.2019).

${ }^{84}$ Соловьёв Э.И. Кант: знание, вера и нравственность. URL: https://scepsis.net/library/ id_2641.html (дата звернення: 8.01.20)

85 Лосев А.Ф., Шестаков В.П. История эстетических категорий. М.: Искусство, 1965. C. 330 .
} 
optimism, Marxist messianism, scientistic progressism and other ideological "religions". Even in our time when the memory of the monstrous consequences of the ideological sacralizations of the twentieth century should be still fresh, we have, in essence, all the same practices but already in new, hybrid forms. The corresponding mentality continues to reproduce "evaporations", poisonous for democracy and civic society. In this sense, to be a European is to a great extent to be a Kantian. And vice versa. That is why the radicals of all stripes hate Kant. Without knowing his works, they purely intuitively feel in him the spokesman of a completely different mentality. It is not by chance that "new" passionaries recently splashed out paint on the great philosopher's monument in Kaliningrad (Russian federation) ${ }^{86} \ldots$

Kant uses the laughter discourse as one of the means of a fundamental distinction between the proper transcendental and the transcendental claims of the profane. In other words, he formulates the deep basis of what is called freedom of conscience in European law. And he does this not for the sake of transcendental being, which does not need his protection, but for the sake of renewing transcendental knowledge; not for the sake of a letter, but for the sake of the Spirit.

\section{CONCLUSIONS}

The analysis of Kant's understanding of laughter and humour shows that the statements of the Konigsberg thinker do not fit within the limits of any one theory of laughter, be it the Incongruity Theory or another theory. In fact, Kant demonstrates the subject being studied, changing various optics of its vision, and laying the foundation for the heterogeneous understanding of the phenomenon of laughter. In addition, we believe that the laughter discourse (philosophical irony) is directly related to the meta-basis of the philosopher's critical discourse.

This exploration is a part of the research program of grant Erasmus +, the Jean Monnet Project "European Anti-totalitarian Practices" (№ 599704-EPP-1-2018-1-UA-EPPJMO-MODULE).

\section{SUMMARY}

Today, the Kantian understanding of laughter has gained in the philosophical literature an almost textbook status. This situation does not take into account the polysemantic nature of philosophical quotes in general and

\footnotetext{
${ }^{86}$ В Калининграде облили краской памятник Канту и разбросали листовки с призывом отказаться от “имени врага”. URL: https://meduza.io/news/2018/11/27/v-kaliningrade-oblilikraskoy-pamyatnik-kantu-i-razbrosali-listovki-s-prizyvom-otkazatsya-ot-imeni-vraga (дата звернення: 11.11. 2019).
} 
Kantian statements about laughter, in particular. Moreover, in the literature, prevails the tendency for a mono-paradigmatic interpretation of the great German philosopher's point of view. Most often, his views are classified as belonging to the Incongruence theory. Overcoming this approach, we propose a more contextually adequate heterogeneous theory. Moreover, we see Kant's theory not only as poly-paradigmatic, but also dynamic, manifesting the process of development. The contemporary philosophy enables us to see some contradictions in Kant's views, the reasons for which we will try to understand by means of explication of some a priori moral attitudes of the philosopher. In addition to interpreting Kant's immediate statements about the phenomenon of laughter, we will try to take the problem a little deeper. We propose a hypothesis suggesting an essential relationship between Kant's critical method and his specific philosophical irony.

\section{REFERENCES}

1. Бондаренко А.В. Языковая онтология смеховой культуры. URL: http://cheloveknauka.com/yazykovaya-ontologiya-smehovoy-kultury (дата звернення: 15.12.2019).

2. Berger Arthur Asa. An Anatomy of Humor. New Brunswick, N.J., U.S.A.: Transaction Publishers, 1993. URL: https://books.google.com.ua/ books?id=aZkRJJnc6BUC $\&$ printsec $=$ frontcover $\& \mathrm{hl}=\mathrm{ru} \# \mathrm{v}=$ onepage $\& \mathrm{q} \& \mathrm{f}=\mathrm{fal}$ se (дата звернення: 10.12.2019).

3. Philosophy of Humor. Stanford Encyclopedia of Philosophy. URL: https://plato.stanford.edu/entries/humor/ (дата звернення: 15.11.2019).

4. Olin L. Questions for a Theory of Humor. Philosophy Compass. 2016. 11 (6). P. 338-350.

5. Amir Lydia. Humor and the good life in modern philosophy: Shaftesbury, Hamann, Kierkegaard. Albany: State University of New York Press, 2014. 393 p.

6. Карасев Л.В. Философия смеха. URL: http://teologia.ru/www/bibliot eka/esthetika/karasev.htm (дата звернення: 10.10.2019).

7. Жан-Поль Приготовительная школа эстетики. Вступ. статья, сост., пер. и коммент. Ал. В. Михайлова. М.: Искусство, 1981. 448 с.

8. Пропп В.Я. Проблемы комизма и смеха. Ритуальный смех в фольклоре (по поводу сказки о Несмеяне). М.: Лабиринт, 1999. URL: https://www.gumer.info/bibliotek_Buks/Culture/propp/02.php (дата звернення: 1.10.2019).

9. Сычев А.А. Природа смеха или Философия комического. Саранск: Изд-во Мордовского ун-та, 2003. 176 с.

10. Bardon A. The Philosophy of Humor. URL: https://www.academia.edu/ 9819670/The_Philosophy_of_Humor (дата звернення: 4.01.2018). 
11. Monro D.H. Theories of Humor. Writing and Reading Across the Curriculum 3rd ed. Laurence Behrens and Leonard J. Rosen, eds. Glenview, IL: Scott, Foresman and Company. 1988. P. 349-355. URL: https://msu.edu/ jdowell/monro.html (дата звернення: 4.06.19).

12. Aristotle. The Poetics of Aristotle edited with critical notes and a translation by S.H. Batcher Third edition revised. New York: The Macmillan Company. 1902. URL: https://www.stmarys-ca.edu/sites/default/files/ attachments/files/Poetics.pdf (дата звернення: 5.06.19).

13. Столяр М. Філософія сміху і гумору в сучасному історикофілософському дискурсі. Огляд книги: Amir, L. (2014). Humor and the Good Life in Modern Philosophy: Shaftesbury, Hamann, Kierkegaard. Albany: State University of New York Press. Sententiae. 2018. 37:1. C. $168-178$.

14. Giamario P.T. "Making reason think more" (laughter in Kant's aesthetic philosophy). URL: https://www.academia.edu/35344281/Making Reason_Think_More_Laughter_in_Kants_Aesthetic_Philosophy (дата звернення: 4.01.2020).

15. Куприянов В.А. Место смеха в системе философии Гегеля и его отношение к идеалу в контексте искусства. URL: http://anthropology.ru/ $\mathrm{ru} /$ text/kupriyanov-va/mesto-smeha-v-sisteme-filosofii-gegelya-i-ego-otnosheniek-idealu-v-kontekste (дата звернення: 5.01.2020).

16. Straus I.J. Incongruity Theory and the Explanatory Limits of Reason. URL: https://scholarworks.uvm.edu/hcoltheses/26/ (дата звернення: 9.01.2020).

17. Carus P. On the philosophy of laughing. The Monist. 1998. Vol. 8. № 2. P. 250-272.

18. Smuts A. Humor. Internet Encyclopedia of Philosophy. URL: https://www.iep.utm.edu/humor/ (дата звернення: 11.01.2020).

19. Kant's Critique of Judgement, translated with Introduction and Notes by J.H. Bernard (2nd ed. revised). London: Macmillan. URL: http://oll.libertyfund.org/titles/kant-the-critique-of-judgement (дата звернення: 7.05.2019).

20. Kant I. Kritik der Urteilskraft. Fünfte auflage. Herausgegeben, eingeleitet und mit einem personen - und sachregister versehen von Karl Vorländer. Leipzig: Verlag von Felix Meiner, 1922. 394 s.

21. Чупров А. Смех как атрибут человека. Топос: литературный и философский журнал. 2018. URL: http://www.topos.ru/article/ ontologicheskie-progulki/smeh-kak-atribut-cheloveka. (дата звернення: 22.01.18).

22. Spencer H. Essays: Scientific, Political and Speculative. 1854. Vol. 2. URL: https://oll.libertyfund.org/titles/spencer-essays-scientific-political-andspeculative-vol-2 (дата звернення: 15.01.18). 
23. Bergson, H. Laughter: An essay on the meaning of the comic. URL: https://www.templeofearth.com/books/laughter.pdf (дата звернення: 18.02.18).

24. Пролеев С.В. Там, где смеха нет // С.В. Пролеев / $\Delta$ б́ $\alpha$ /ДОКСА. 3б. наук. праць $з$ філософії та філології. - Вип. 13. Сміх та серйозність: множинність видів та взаємин. - Одеса: Видавництво Одеського національного університету, 2008. - С. 27-32.

25. Kant I. Anthropology from a Pragmatic Point of View. 1996. URL:

https://books.google.com.ua/books?id=TbkVBMKz418C\&printsec=frontc over\&hl=ru\#v=onepage \&q\&f=false (дата звернення: 10.05.2019).

26. Kant I. Anthropologie in pragmatischer Hinsicht. Fünfte Auflage. Herausgegebe, eingeleitet und mit Personen- und Sachregister versehen von Karl Vorländer. Leipzig: Verlag von Felix Meiner, 1912. 328 s.

27. Ойзерман Т.И. К вопросу о знаменитом тезисе Канта: “...мне пришлось ограничить (aufheben) знание, чтобы освободить место вере...”. URL: http://kant-online.ru/wp-content/uploads/2014/06/Full.pdf (дата звернення: 10.06.2019).

28. Батракова И.А. Отношение знания и веры в критической философии Канта. URL: http://www.smyrnyh.com/?page_id=392 (дата звернення: 10.06.2019).

29. Мотрошилова Н.В. Отношение знания и веры в “Критике чистого разума" Иммануила Канта. Материалы Международной научной конференции "Проблема веры и знания в немецкой классической философии”. СПб.: Изд-во С.-Петерб. ун-та, 2008. URL:

https://www.rhga.ru/science/conferences/rusm/russian_thought/vera_i_znanie. php (дата звернення: 28.12.2019)

30. Соловьёв Э.И. Кант: знание, вера и нравственность. URL: https://scepsis.net/library/id_2641.html (дата звернення: 8.01.2020)

31. Лосев А.Ф., Шестаков В.П. История эстетических категорий. М.: Искусство, 1965. 374 с.

32. В Калининграде облили краской памятник Канту и разбросали листовки с призывом отказаться от “имени врага". URL: https://meduza.io/ news/2018/11/27/v-kaliningrade-oblili-kraskoy-pamyatnik-kantu-i-razbrosalilistovki-s-prizyvom-otkazatsya-ot-imeni-vraga (дата звернення: 11.11. 2019).

\section{Information about the author:} Stoliar M. B.,

Doctor of Sciences in Philosophy, Associated Professor, Head of the Chair of Philosophy and Cultural Studies,

Department of Philology at T. H. Shevchenko, National University "Chernihiv Colehium" 70, Hetmana Polubotka str., Chernihiv, 14000, Ukraine 